Tropical Journal of Pharmaceutical Research March 2020; 19 (3): 513-517

ISSN: $1596-5996$ (print); 1596-9827 (electronic)

(C) Pharmacotherapy Group, Faculty of Pharmacy, University of Benin, Benin City, 300001 Nigeria.

\title{
Analgesic effect of flurbiprofen ester and its effect on serum inflammatory factors and B-endorphin expression in rats with incision pain
}

\author{
Xiaomin Ye, Xianhua Ye, Nannan Ye* \\ Department of Anesthesiology, The First People's Hospital of Wen Ling, Wenling, PR China
}

*For correspondence: Email: jezz65@163.com

Sent for review: 18 December 2019

Revised accepted: 29 February 2020

\begin{abstract}
Purpose: To study the analgesic effect of flurbiprofen ester in rats with incision pain, and its effect on serum inflammatory factors and $\beta$-endorphin expression.

Methods: Seventy-five (75) healthy rats with foot contraction threshold induced by basic mechanical stimulation were randomly assigned to control, model control and treatment groups. Flurbiprofen was administered in 3 doses: 5,10 and $15 \mathrm{mg} / \mathrm{kg}$. Then, $3 \mathrm{~mL}$ of ventricular blood was taken from anesthetized rats and the serum levels of tumor necrosis factor- $\alpha$ (TNF- $\alpha$ ), interleukin-1 $\beta$, interleukin- 6 and $\beta$-endorphin were measured. The expression of $\beta$-endorphin in the spinal cord of rats with lumbar enlargement and ARC was determined.

Results: The TNF- $\alpha$, interleukin-1 $\beta$ and interleukin-6 concentrations were significantly lower in treatment group than in model rats, and decreased with time and dose $(p<0.05)$. In the treatment group, the level of serum $\beta$-endorphin decreased with increase in dose at $1 \mathrm{~h}$, but increased with increase in dose at $5 h$ and $10 h(p<0.05)$. The levels of $\beta$-endorphin in the spinal cord, was significantly lower in model rats than in control rats $(p<0.05)$.

Conclusion: Pre-administration of flurbiprofen ester reduces serum inflammatory factors and upregulates $\beta$-endorphin expression in rats with incision pain. Thus, it flurbiprofen exerts analgesic effect.
\end{abstract}

Keywords: Flurbiprofen ester, Incision pain, Rat, Analgesia, Inflammatory factor, $\beta$-endorphin

\begin{abstract}
This is an Open Access article that uses a fund-ing model which does not charge readers or their institutions for access and distributed under the terms of the Creative Commons Attribution License (http://creativecommons.org/licenses/by/4.0) and the Budapest Open Access Initiative (http://www.budapestopenaccessinitiative.org/read), which permit unrestricted use, distribution, and reproduction in any medium, provided the original work is properly credited.

Tropical Journal of Pharmaceutical Research is indexed by Science Citation Index (SciSearch), Scopus, International Pharmaceutical Abstract, Chemical Abstracts, Embase, Index Copernicus, EBSCO, African Index Medicus, JournalSeek, Journal Citation Reports/Science Edition, Directory of Open Access Journals (DOAJ), African Journal Online, Bioline International, Open-J-Gate and Pharmacy Abstracts
\end{abstract}

\section{INTRODUCTION}

Endogenous opioid peptide (EOP) exerts an opioid effect. It is classified into enkephalin, endorphin, dynorphin and nea porphin. Endogenous opioid peptide (EOP) relieves conduction of pain signals through binding to the opioid receptor on the target cell membrane, thereby exerting analgesic effect [1]. The effect of endorphin is the strongest among the members of EOP family, and the distribution of endorphin in the body is very extensive. PEnkephalin is present in the nervous system, endocrine organs, digestive tract, placenta, and amniotic fluid [2,3]. Under normal conditions, the level of endorphin in the body is low. However, when stress reaction occurs, there is increased release of endorphin, leading to enhancement of 
cerebral ischemic brain edema, and inhibition of the frequency and the amplitude of respiratory motion $[4,5]$.

The analgesic effect of endorphin is strong, and it enhances the release of hormones such as auxin, prolactin, somatostatin and glucagon [6]. Surgical wounds cause tissue injury, release of inflammatory factors, inflammatory reactions and hyperalgesia [7]. Flurbiprofen axetil (FA), a cyclooxygenase inhibitor with the effect of antiinflammatory, antipyretic, anti-rheumatism and analgesic properties, and it is clinically used for treating post-operative and various cancer pain [8]. The present study was carried out to investigate the analgesic effect of FA preadministration, and its effect on the expression of serum inflammatory factors and endorphin in rats.

\section{EXPERIMENTAL}

\section{General information}

A total of 75 SPF-grade SD male rats without primary disease were used. The biological license number of experimental animals was SCXK (GUI) 2007-000. The rats were 6.0 - 8.0 weeks old, with mean body weight of $154.11 \pm$ $23.42 \mathrm{~g}$. Approval for the study was received from the ethics committee of our hospital (approval no. 20190216) and the study carried out in line with international guidelines for animal studies [9].

\section{Treatments}

Five groups of rats were used (15 rats per group). In control rats, $1 \mathrm{ml}$ fat milk was administered via tail vein injection. After $30 \mathrm{~min}$, the rats were subjected to inhalation of $1 \%$ sevoflurane for 5 min without surgery. Rats in model group were treated with painful plantar incision 30 min after intravenous injection of $1 \mathrm{ml}$ fat milk, and inhalation of $1 \%$ sevoflurane for 5 min. Rats in the low, medium and high treatment groups were injected in the tail vein with flurbiprofen (diluted with fat milk) at levels corresponding to 5,10 and $15 \mathrm{mg} / \mathrm{kg}$ ), in that order, for $30 \mathrm{~min}$.

\section{Painful plantar incision}

After inhalation of $1 \%$ sevoflurane anesthesia, an incision of about $1 \mathrm{~cm}$ was made in the proximal plantar of each rat. The skin was cut open, the muscles of the sole were cut lengthwise, and the wound was sewn up after pressing down, without bleeding.

\section{Therapeutic indices}

The mechanical stimulation and foot contraction (PMWT) of each rat was measured 1, 5 and $10 \mathrm{~h}$ after the operation using von Frey electronic pain detector. The rats were put in a quiet environment, and the mean value of PMWT was obtained for three consecutive tests.

For serum indices, 5 rats in each group were randomly selected at 1,5 and $10 \mathrm{~h}$ after surgery. After abdominal deep anesthesia, $3 \mathrm{~mL}$ of ventricular blood was collected from the rats and kept at a temperature of $4{ }^{\circ} \mathrm{C}$ for $20 \mathrm{~min}$. Thereafter, it was centrifuged at $3500 \mathrm{rpm}$ for 5 min, and the serum was refrigerated at $-80{ }^{\circ} \mathrm{C}$ to avoid repeated freezing and thawing. Serum TNF- $\alpha$, IL-1, IL- 6 , and $\beta$-endorphin levels were determined using ELISA.

Rat spinal cord was placed in $4 \%$ paraformaldehyde fixative solution and kept in a $4 \quad{ }^{\circ} \mathrm{C}$ refrigerator prior to examination. Immunohistochemical staining and image analysis were used to determine the expression level of beta endorphins in the rat spinal cord.

\section{Statistical analysis}

Data are presented mean \pm SD. Qualitative data are presented as \%. Comparison between two groups was performed with $t$-test, while comparison amongst groups was carried out using Chi square test. Ridit test was used to compare grade data. All statistical analyses were done with SPSS20.0 software package. Statistical significance was fixed at $p<0.05$.

\section{RESULTS}

\section{Changes in PMWT level in rats}

As shown in Table 1, basic PMWT values of rats were comparable amongst the groups $(p>0.05)$. The PMWT of rats in the model control group was significantly lower than that in the control group at each time point, while PMWT of rats in the treatment group was significantly higher than that in the model control group at each time point $(p<0.05)$.

\section{Changes in serum inflammatory factors}

The serum levels of the measured cytokines were higher in model rats than in control at each time point, and increased with time. However, serum cytokine levels were markedly reduced in the treatment groups, relative to model rats, and decreased along with time and dose gain ( $p<$ 0.05; Table 2, Table 3 and Table 4). 
Table 1: Changes in PMWT level at different times after operation $(n=15)$

\begin{tabular}{|c|c|c|c|c|}
\hline \multirow{2}{*}{ Group } & \multicolumn{4}{|c|}{ PMWT(g) } \\
\hline & Baseline & $1 h$ & $5 h$ & $10 h$ \\
\hline \multirow{2}{*}{ Control } & $45.16 \pm$ & 44.26 & 44.83 & 44.71 \\
\hline & 2.25 & \pm 1.49 & \pm 1.29 & \pm 2.85 \\
\hline Model & $\begin{array}{c}44.89 \pm \\
1.13\end{array}$ & $\begin{array}{c}20.48 \pm \\
1.71^{\mathrm{a}}\end{array}$ & $\begin{array}{c}21.48 \pm \\
2.83^{a}\end{array}$ & $\begin{array}{c}22.56 \pm \\
1.85^{\mathrm{a}}\end{array}$ \\
\hline $\begin{array}{l}\text { Low } \\
\text { dose }\end{array}$ & $\begin{array}{c}45.26 \pm \\
2.10\end{array}$ & $\begin{array}{c}28.45 \pm \\
1.56^{\mathrm{ab}}\end{array}$ & $\begin{array}{c}27.48 \pm \\
1.73^{\mathrm{ab}}\end{array}$ & $\begin{array}{c}30.79 \pm \\
1.65^{\mathrm{ab}}\end{array}$ \\
\hline $\begin{array}{l}\text { Mediu } \\
\text { m dose }\end{array}$ & $\begin{array}{c}45.94 \pm \\
2.14\end{array}$ & $\begin{array}{l}31.40 \pm \\
2.71^{\mathrm{abc}}\end{array}$ & $\begin{array}{l}31.05 \pm \\
2.78^{\mathrm{abc}}\end{array}$ & $\begin{array}{l}34.56 \pm \\
2.52^{\mathrm{abc}}\end{array}$ \\
\hline $\begin{array}{l}\text { High } \\
\text { dose }\end{array}$ & $\begin{array}{c}44.76 \pm \\
1.86\end{array}$ & $\begin{array}{l}34.52 \pm \\
2.33^{\mathrm{abcd}}\end{array}$ & $\begin{array}{l}35.78 \pm \\
2.84^{\text {abcd }}\end{array}$ & $\begin{array}{l}40.15 \pm \\
3.10^{\text {abcd }}\end{array}$ \\
\hline
\end{tabular}

Table 2: Changes in serum TNF- $\alpha$ levels at different times after operation $(n=15)$

\begin{tabular}{lccc}
\hline \multirow{2}{*}{ Group } & \multicolumn{3}{c}{ TNF- $\boldsymbol{\alpha}(\mathbf{p g} / \mathrm{mL})$} \\
\cline { 2 - 4 } & $\mathbf{1} \boldsymbol{h}$ & $\mathbf{5 h}$ & $\mathbf{1 0 h}$ \\
\hline \multirow{2}{*}{ Control } & $64.16 \pm$ & $78.18 \pm$ & $85.19 \pm$ \\
& 10.48 & 11.43 & 13.76 \\
Model & $223.19 \pm$ & $246.79 \pm$ & $276.48 \pm$ \\
Low & $21.46^{\mathrm{a}}$ & $23.15^{\mathrm{a}}$ & $30.41^{\mathrm{a}}$ \\
dose & $205.17 \pm$ & $176.48 \pm$ & $164.73 \pm$ \\
Medium & $13.74^{\mathrm{ab}}$ & $16.48^{\mathrm{ab}}$ & $20.14^{\mathrm{ab}}$ \\
dose & $182.18 \pm$ & $165.48 \pm$ & $151.43 \pm$ \\
High & $12.43^{\mathrm{abc}}$ & $10.44^{\mathrm{abc}}$ & $14.73^{\mathrm{abc}}$ \\
dose & $162.89 \pm$ & $130.76 \pm$ & $102.75 \pm$ \\
\hline Data are mean \pm SD; ${ }^{\mathrm{a}} p<0.05$, vs control; ${ }^{\mathrm{b}} p<0.05$, \\
vs model, ${ }^{\mathrm{c}} p<0.05$, vs low concentration group; ${ }^{\mathrm{d}} p<$ \\
0.05, vs medium concentration group
\end{tabular}

Table 3: Changes in serum IL-6 levels at different times after operation

\begin{tabular}{|c|c|c|c|}
\hline Group & $\begin{array}{c}\text { IL-6 } \\
(\mathrm{pg} / \mathrm{mL}) 1 h\end{array}$ & $\begin{array}{c}\text { IL-6 } \\
(\mathrm{pg} / \mathrm{mL}) 5 h\end{array}$ & $\begin{array}{c}\mathrm{IL}-6 \\
(\mathrm{pg} / \mathrm{mL}) \\
10 \mathrm{~h}\end{array}$ \\
\hline Control & $\begin{array}{c}51.46 \pm \\
10.45\end{array}$ & $\begin{array}{c}53.48 \pm \\
11.86\end{array}$ & $\begin{array}{c}56.78 \pm \\
11.49\end{array}$ \\
\hline Model & $\begin{array}{c}124.78 \pm \\
18.41^{\mathrm{a}}\end{array}$ & $\begin{array}{c}141.76 \pm \\
20.15^{\mathrm{a}}\end{array}$ & $\begin{array}{c}168.43 \pm \\
23.48^{\mathrm{a}}\end{array}$ \\
\hline Low dose & $\begin{array}{c}116.48 \pm \\
8.41^{\mathrm{ab}}\end{array}$ & $\begin{array}{l}95.46 \pm \\
16.18^{\mathrm{ab}}\end{array}$ & $\begin{array}{l}90.15 \pm \\
16.43^{\mathrm{ab}}\end{array}$ \\
\hline $\begin{array}{l}\text { Medium } \\
\text { dose }\end{array}$ & $\begin{array}{c}100.16 \pm \\
3.76^{\mathrm{abc}}\end{array}$ & $\begin{array}{l}95.15 \pm \\
14.73^{\mathrm{abc}}\end{array}$ & $\begin{array}{l}88.45 \pm \\
15.22^{\mathrm{abc}}\end{array}$ \\
\hline $\begin{array}{l}\text { High } \\
\text { dose }\end{array}$ & $\begin{array}{l}85.79 \pm \\
2.86^{\text {abcd }}\end{array}$ & $\begin{array}{c}72.41 \pm \\
13.11^{\mathrm{abcd}}\end{array}$ & $\begin{array}{c}61.74 \pm \\
13.77^{\mathrm{abcd}}\end{array}$ \\
\hline $\begin{array}{l}\text { Data are } \\
\text { vs model, } \\
0.05 \text {, vs } n\end{array}$ & um concer & $\begin{array}{l}0.05 \text {, vs con } \\
\text { v concentrati } \\
\text { tion group }\end{array}$ & ${ }^{b} p<0.0$ \\
\hline
\end{tabular}

\section{Serum and spinal cord levels of beta- endorphins}

As shown in Tables 5 and 6 , serum level of betaendorphins in the model group was significantly different from those in the control group $(p<$
0.05). The serum level of beta-endorphins in the treatment group decreased with increase in dose at $1 \mathrm{~h}$, but increased with increase in dose at 5 and $10 \mathrm{~h}(p<0.05)$.

In the spinal cord, the levels of beta-endorphin in the model control group were significantly lower than those in the control group at 5 and $10 \mathrm{~h}$, while beta-endorphin levels were markedly higher in treatment rats than in model rats, and increased with increase in dose $(p<0.05)$.

Table 4: Levels of IL-1 in serum at different time periods after operation $(n=5)$

\begin{tabular}{|c|c|c|c|}
\hline Group & $\begin{array}{c}\text { IL-1及 } \\
(\mathrm{pg} / \mathrm{mL}) 1 h\end{array}$ & $\begin{array}{c}\text { IL-1及 } \\
(\mathrm{pg} / \mathrm{mL}) 5 h\end{array}$ & $\begin{array}{c}\mathrm{IL-1 \beta} \\
(\mathrm{pg} / \mathrm{mL}) 10 \mathrm{~h}\end{array}$ \\
\hline Control & $\begin{array}{c}10.45 \pm \\
1.53\end{array}$ & $\begin{array}{c}12.46 \pm \\
2.73\end{array}$ & $14.86 \pm 3.44$ \\
\hline Model & $\begin{array}{c}24.76 \pm \\
3.15^{\mathrm{a}}\end{array}$ & $\begin{array}{c}28.44 \pm \\
3.46^{\mathrm{a}}\end{array}$ & $\begin{array}{c}32.41 \pm \\
4.15^{\mathrm{a}}\end{array}$ \\
\hline $\begin{array}{l}\text { Low } \\
\text { dose }\end{array}$ & $\begin{array}{c}23.56 \pm \\
2.74^{\mathrm{ab}}\end{array}$ & $\begin{array}{c}20.17 \pm \\
2.15^{\mathrm{ab}}\end{array}$ & $\begin{array}{c}17.44 \pm \\
2.81^{\mathrm{ab}}\end{array}$ \\
\hline $\begin{array}{l}\text { Medium } \\
\text { dose }\end{array}$ & $\begin{array}{l}21.36 \pm \\
2.16^{\mathrm{abc}}\end{array}$ & $\begin{array}{l}18.73 \pm \\
4.51^{\mathrm{abc}}\end{array}$ & $\begin{array}{l}16.77 \pm \\
3.46^{\mathrm{abc}}\end{array}$ \\
\hline $\begin{array}{l}\text { High } \\
\text { dose }\end{array}$ & $\begin{array}{l}19.21 \pm \\
3.31^{\text {abcd }}\end{array}$ & $\begin{array}{l}16.23 \pm \\
2.56^{\mathrm{abcd}}\end{array}$ & $\begin{array}{l}12.77 \pm \\
2.56^{\text {abcd }}\end{array}$ \\
\hline \multicolumn{4}{|c|}{$\begin{array}{l}\text { Data are mean } \pm \mathrm{SD} ;{ }^{\mathrm{a}} p<0.05 \text {, compared with the } \\
\text { control group; }{ }^{\mathrm{b}} p<0.05 \text {, compared with the model } \\
\text { control group, }{ }^{\mathrm{c} p}<0.05 \text {, compared with the low } \\
\text { concentration group; }{ }^{d} p<0.05 \text {, compared with the } \\
\text { medium concentration group }\end{array}$} \\
\hline
\end{tabular}

\section{DISCUSSION}

Pain is an unpleasant feeling that accompanies substantive or potential tissue injury. With advances in clinical technology, the mechanism of pain has become one of the areas of interest for medical scholars [10]. Injury to the body induces the release of a large number of inflammatory factors and cytokines which lead to different degrees of inflammatory reactions and production of pain [11]. The NK cells and T lymphocytes are produced by macrophages during stress, and they interact with many receptors in the CNS and promote the synthesis of pain mediators in nerve cells. They also promote the release of inflammatory factors such as IL-1 $\beta$ and IL-6 [12].

Tumor necrosis factor alpha (TNF- $\alpha$ ) is often used as an index for evaluating surgical and early traumatic tissue injuries [13]. Interleukins (ILs) are lymphoid factors which interact with leukocytes and immune cells. They transmit information, regulate the activation of immune cells, and also mediate the proliferation and differentiation of $T$ cells and $B$ cells, which are important in inflammatory response, among which IL- $1 \beta$ and IL- 6 are the most typical. 
Table 5: Serum levels of $\beta$-endorphin in rats at different times after operation $(n=15)$

\begin{tabular}{|c|c|c|c|}
\hline Group & $\beta$-endorphin (pg/mg) 1h & $\beta$-endorphin (pg/mg) $5 h$ & $\beta$-endorphin (pg/mg) 10h \\
\hline Control & $23.45 \pm 5.76$ & $24.89 \pm 6.43$ & $26.49 \pm 7.81$ \\
\hline Model & $27.89 \pm 5.45^{a}$ & $15.49 \pm 3.86^{a}$ & $13.48 \pm 3.41^{a}$ \\
\hline Low dose & $23.49 \pm 4.16^{\mathrm{ab}}$ & $16.46 \pm 3.45^{a}$ & $21.46 \pm 5.22^{\mathrm{ab}}$ \\
\hline Medium dose & $20.26 \pm 4.29^{a b c}$ & $23.34 \pm 4.56^{\mathrm{abc}}$ & $26.98 \pm 7.58^{a b c}$ \\
\hline High dose & $17.98 \pm 7.44^{\mathrm{abcd}}$ & $27.48 \pm 5.23^{\mathrm{abcd}}$ & $27.84 \pm 6.48^{\mathrm{abcd}}$ \\
\hline
\end{tabular}

Table 6: Levels of $\beta$-endorphin in spinal cord of rats at different times after operation

\begin{tabular}{lccc}
\hline Group & $\boldsymbol{\beta}$-endorphin $(\mathbf{p g} / \mathbf{m g}) \mathbf{1 h}$ & $\boldsymbol{\beta}$-endorphin $(\mathbf{p g} / \mathbf{m g}) \mathbf{5 h}$ & $\boldsymbol{\beta}$-endorphin $(\mathbf{p g} / \mathbf{m g}) \mathbf{1 0 h}$ \\
\hline Control & $0.54 \pm 0.12$ & $0.55 \pm 0.09$ & $0.53 \pm 0.04$ \\
Model & $0.56 \pm 0.13$ & $0.42 \pm 0.08^{\mathrm{a}}$ & $0.38 \pm 0.02^{\mathrm{a}}$ \\
Low dose & $0.63 \pm 0.21^{\mathrm{ab}}$ & $0.65 \pm 0.16^{\mathrm{ab}}$ & $0.68 \pm 0.15^{\mathrm{ab}}$ \\
Medium dose & $0.78 \pm 0.23^{\mathrm{abc}}$ & $0.81 \pm 0.18^{\mathrm{abc}}$ & $0.79 \pm 0.22^{\mathrm{abc}}$ \\
High dose & $0.88 \pm 0.25^{\mathrm{abcd}}$ & $0.89 \pm 0.21^{\mathrm{abcd}}$ & $0.92 \pm 0.12^{\mathrm{abcd}}$ \\
\hline
\end{tabular}

Data are mean \pm SD. ${ }^{a} p<0.05$, vs control; ${ }^{b} p<0.05$, vs model, ${ }^{c} p<0.05$, vs low dose group; ${ }^{d} p<0.05$, vs medium concentration group

It has been reported that IL-1 $\beta$ and IL-6 regulate the conduction velocity of pain signal from spinal cord to the brain by acting on pain nerve neurons [14].

In this study, there was no significant difference in the basic value of PMWT among the three groups. The PMWT of the model control group was significantly lower than that of the control group at each time point, while the PMWT of the treatment group was significantly higher than that of the model control group at each time point The serum levels of the measured cytokines were higher in model rats than in control at each time point, and increased with time. However, serum cytokine levels were markedly reduced in the treatment groups, relative to model rats, and decreased along with time and dose gain. These results suggest that FA inhibits hyperalgesia, has obvious analgesic effect, reduces the levels of inflammatory factors, and inhibits inflammation in a dose-dependent fashion.

$\beta$-Endorphin, an important inhibitory neurotransmitter in the pain regulation pathway, significantly inhibits the effect of the sensory neurotransmitter substance $P$. Deficiency of $\beta$ endorphin may lead to a certain degree of hyperalgesia [15]. In this study, changes in $\beta$ endorphin levels in serum and spinal cord of rats were determined. $\beta$-Endorphin levels differed markedly between rats in model and control groups. In the treatment group, the level of serum $\beta$-endorphin decreased with increase in FA dose at $1 \mathrm{~h}$, but increased with increase in dose at $5 \mathrm{~h}$ and $10 \mathrm{~h}$. In the spinal cord, $\beta$ endorphin levels in the model control group were significantly lower than those in the control group at 5 and $10 \mathrm{~h}$, while $\beta$-endorphin levels in the treatment group were significantly higher than those in the model control group, and increased with increase in FA dose. Thus, the analgesic effect of FA may be related to increases in $\beta$ endorphin level, which is consistent with the report of Luan Yuanhang [16].

\section{CONCLUSION}

Pre-administration of FA produces an analgesic effect by lowering serum levels of inflammatory factors, inhibition of inflammatory response, enhancement of anti-inflammatory immune response, reduction of the risk of infection, and upregulation of the expression of $\beta$-endorphin.

\section{DECLARATIONS}

\section{Conflict of interest}

No conflict of interest is associated with this work.

\section{Contribution of authors}

This study was done by the authors named in this article, and the authors accept all liabilities resulting from claims which relate to this article and its contents. The study was conceived and designed by Nannan Ye; Xiaomin Ye, Xianhua Ye, Nannan Ye collected and analyzed the data; Xiaomin Ye wrote the text. All authors read and approved the manuscript for publication.

\section{Open Access}

This is an Open Access article that uses a funding model which does not charge readers or their institutions for access and distributed under the terms of the Creative Commons Attribution 
License (http://creativecommons.org/licenses/by/ 4.0) and the Budapest Open Access Initiative (http://www.budapestopenaccessinitiative.org/rea d), which permit unrestricted use, distribution, and reproduction in any medium, provided the original work is properly credited.

\section{REFERENCES}

1. Li N, Han ZL, Wang ZL, Xing $Y H$, Sun $Y L$, Li XH, Song $J J$, Zhang $T$, Zhang $R$, Zhang $M N$, et al. $B N-9$, a chimeric peptide with mixed opioid and neuropeptide FF receptor agonistic properties, produces nontoleranceforming antinociception in mice. Br J Pharmacol 2016; 173(11): 1864-1880.

2. Sheikhhosseini E, Balalaie S, Bigdeli M. Synthesis of Nocistatin C-terminal and it's Amide Derivatives as an Opioid Peptide. Iran J Pharm Res 2016; 15(3): 337-342.

3. Wang ZL, Li N, Wang P, Tang HH, Han ZL, Song JJ, Li $X H$, Yu HP, Zhang $T$, Zhang $R$, et al. Pharmacological characterization of $\mathrm{EN}-9$, a novel chimeric peptide of endomorphin-2 and neuropeptide FF that produces potent antinociceptive activity and limited tolerance. Neuropharmacol 2016; 108: 364-372.

4. Li X, Zhu J, Tao Y, Tao K. Elevated endogenous opioids in obstructive jaundice: The possible skin mechanisms. Med Hypotheses 2018; 116: 119-121.

5. Olson KM, Lei W, Keresztes A, LaVigne J, Streicher JM. Novel Molecular Strategies and Targets for Opioid Drug Discovery for the Treatment of Chronic Pain. Yale J Biol Med 2017; 90: 97-110.

6. Stathopoulos AM, Helena CV, Cristancho-Gordo $R$, Gonzalez-Iglesias AE, Bertram $R$. Influence of dynorphin on estradiol- and cervical stimulation-induced prolactin surges in ovariectomized rats. Endocrine 2016; 53(2): 585-594.

7. Zhang AC. Effects of pregabalin oral administration on plasma substance $P$ and beta-endorphin in patients before radical mastectomy. Pract Cancer J 2016; 31(9): 1438-1440.

8. Zhao XD, Ji LT. Flurbiprofen axetil: Analgesic effect and adverse reaction. Pak J Pharm Sci 2018; 31(3): 11631167.

9. World Health Organization. Principles of laboratory animal care. WHO Chron 1985; 39: 51-56.

10. Xia $Y$, Stadler $D$, Lucifora J, Reisinger $F$, Webb $D$. Interferon- $y$ and Tumor Necrosis Factor- $\alpha$ Produced by $T$ Cells Reduce the HBV Persistence Form, cccDNA, Without Cytolysis. Gastroenterol 2016; 150(1): 194-205.

11. Kumawat K, Pathak SK, Spetz AL, Kundu M, Basu J. Exogenous Nef is an inhibitor of Mycobacterium tuberculosis -induced tumor necrosis factor- $\alpha$ production and macrophage apoptosis. J Biol Chem 2016; 291(2): 665-666.

12. Liang F, Xie S. Puerarin prevents tumor necrosis factor$\alpha$-induced apoptosis of PC12 cells via activation of the PI3K/Akt signaling pathway. Exp Ther Med 2017; 14: 813-818.

13. Bulfon C, Galeotti M, Volpatti D. Medicinal plant extracts modulate respiratory burst and proliferation activity of rainbow trout (Oncorhynchus mykiss) leukocytes. Fish Physiol Biochem 2017; 44(1): 1-9.

14. Ning $Z W$, Luo $X Y$, Wang $G Z, L i Y$, Pan $M X$, Yang $R Q$, Ling $X G$, Huang $S$, Ma XX, Jin SY, et al. MicroRNA-21 Mediates Angiotensin II-Induced Liver Fibrosis by Activating NLRP3 Inflammasome/IL-1 $\beta$ Axis via Targeting Smad7 and Spry1. Antioxid Redox Signal 2016; 27(1): 1-20.

15. $X u$ L, Li ZP. effects of paravertebral nerve block combined with general anesthesia on perioperative blood glucose, beta-endorphin, thf-alpha and il-6 levels in patients undergoing radical esophageal cancer. Mod J Integr Tradit Chin Western Med 2018; 27(8): 892-895.

16. Luan $Y H$, Chai $X Q$, Yu $Q$, Wang $D$, Wei W. Effects of flubiprofen on central endorphin levels in rats with incisional pain. Chin J Anesthesiol 2017; 37: 693-696. 